\title{
PENINGKATAN LATIHAN TERBIMBING DENGAN \\ PENDEKATAN MODEL PEMBELAJARAN \\ KONTSTRUKTIVISME SEBAGAI UPAYA MENINGKATKAN \\ PRESTASI BELAJAR BAHASA INDONESIA SISWA KELAS \\ III SEMESTER I SDN 2 PEGUYANGAN \\ TAHUN PELAJARAN 2017/2018
}

\author{
Oleh \\ Ni Made Sitiasih \\ SDN 2 Peguyangan \\ sitiasihmade@yahoo.co.id
}

\begin{abstract}
ABSTRAK
Pelaksanaan penelitian ini bertujuan untuk mengetahui peningkatkan prestasi belajar siswa kelas III semester I SD Negeri 2 Peguyangan Tahun pelajaran 2017/ 2018 setelah diterapkan metode Latihan terbimbing dengan pendekatan model pembelajaran Kontruktifisme sebagai upaya untuk meningkatkan prestasi belajar siswa akibat penggunaan metode yang kurang variatif yang masih menggunakan model yang terus menerus dinyatakan tanpa teori yang memadai. Setelah data dikumpulkan menggunakan alat berupa tes prestasi belajar siswa dari rata-rata awal 60,5 naik menjadi 68,11 pada siklus I dan naik menjadi 72,56 pada siklus II. Hasil pada siklus II sudah sesuai harapan indicator keberhasilan penelitian oleh karenanya penelitian ini tidak dilanjutkan ke siklus berikutnya. Dengan perolehan data tersebut dapat dipastikan bahwa penerapan metode pendekatan kontruktivisme dalam pelaksanaan proses pembelajaran mampu meningkatkan prestasi belajar siswa sehingga hipotesis yang diajukan dapat diterima.
\end{abstract}

Kata Kunci: Latihan Terbimbing, Pendekatan Konstruktivisme, Bahasa Indonesia, Prestasi Belajar

\section{PENDAHULUAN}

Masalah yang ada di SD

Negeri 2 Peguyangan adalah masalah pembelajaran yang terjadi di kelas III Masalah pembelajaran ini adalah tentang ketidak mampuan peserta didik menerpa ilmu sesuai harapan. Nilai rata-rata kelas ini baru diperoleh 60,5 yang jauh dari KKM mata pelajaran Bahasa Indonesia 70,00 di sekolah ini. Ketuntasan belajarnya baru mencapai 45,94\% sedangkan yang diharapkan adalah mencapai minimal $85 \%$. Untuk itu sebagai seorang guru dituntut lebih giat dalam membuat perencanaan lebih giat dalam melaksanakan.

Dari semua kutipan di atas jelaslah kondisi yang diharapkan bagi seorang guru dalam melaksanakan proses pembelajaran. Guru harus mampu melaksanakannya dengan sebaik-baiknya agar peningkatan mutu pendidikan dapat dicapai sesuai harapan. Kenyataan yang ada di lapangan ternyata tidak sesuai dengan semua harapan tadi, ini terlihat pada data awal penilaian yang dilakukan di SD Negeri 2 Peguyangan kelas III pada semester I tahun Pelajaran 
2017/2018 baru mencapai rata-rata 68,11 dengan ketuntasan belajar baru mencapai $54,05 \%$ Tidak sinkronnya antara yang diharapkan dengan kondisi nyata yang ada di lapangan memunculkan kesenjangan akibat ketidakmampuan guru, kurangnya media pendukung serta kebiasaan anak-anak yang lebih senang bersantai dari pada belajar membuat peneliti harus berupaya untuk memecahkan masalah yang ada. Untuk hal tersebut peneliti mencoba penggunanaan

Pendekatan kontruktivisme untuk dapat mengupayakan peningkatakan prestasi belajar anak. Mengingat permasalahan yang ada adalah permasalahan yang mendesak untuk dipecahkan maka penelitian ini menjadi penting untuk dilaksanakan. Adapun permasalahan dari penelitian ini adalah mengetahui pendekatan model pembelajaran kontruktivistisme dengan latihan terbimbing dapat meningkatkan prestasi belajar Bahasa Indonesia siswa kelas III Semester I SD Negeri 2 Peguyangan Tahun Ajaran 2017/2018.

Pendidikan selama ini terus mengalami pembaharuan untuk menciptakan berbagai metode yang berguna bagi perkembangan zaman untuk memenuhi tuntutan manusia yang semakin hari semakin bermacam dengan berbagai tipe. Tingkat kebutuhan ini menjadikan masyarakat melakukan perubahan kearah yang lebih baik. Pada bidang Pendidikan sendiri mengandung berbagai bidang yang terus mengalami kemajuan, misalnya dalam bidang Pendidikan mengandung Kurikulum yang terus berganti mengikuti tuntutan perkembangan zaman sehingga sistem Pendidikan mengal Pla Kemajuan, bidang ai Pla alnya Kualitas seorang Pengaja. Trurkulím wang berlaku sekaran \$ ini merupak tuk terbaru dari ${ }^{3} 4 \mathrm{p}$ buangan kurikulum

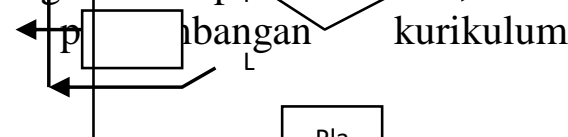

Berbasis Kompetensi yang menekankan pada guru untuk semakin gencar berupaya menggairahkam kembali dunia Pendidikan khususnya yang berkaitan dengan proses pembelajaran. Berbagai penelitian diadakan untuk memajukan dunia Pendidikan. Dalam Penelitian itu digunakan berbagai metode pendekatan misalnya model pembelajaran Konstruktivisme

Peranan guru dalam belajar konstruktivistik guru atau pendidik berperan membantu agar proses pengkonstruksian pengetahuan oleh siswa berjalan lancar. Guru hanya membantu siswa untuk membentuk pengetahuannya sendiri. Guru dituntut lebih memahami jalan pikiran atau cara pandang siswa dalam belajar. Guru tidak dapat mengklaim bahwa satu-satunya cara yang tepat adalah yang sama dan sesuai dengan kemauannya. Peranan kunci guru dalam
interaksi pendidikan pengendalian, yang meliputi:

1. Menumbuhkan kemampuan mengambil keputusan dan bertindak, dengan meningkatkan pengetahuan dan keterampilan siswa.

2. Menyediakan sistem dukungan yang memberikan kemudahan belajar agar siswa mempunyai peluang optimal untuk berlatih.

\section{METODE PENELITIAN}

Dalam penelitian ini, penulis memilih rancangan penelitian tindakan yang disampaikan oleh Kemmis dan Taggart sebagai berikut. 
Subjek penelitian ini adalah semua siswa kelas III Semester I SD Negeri 2 Peguyangan Kecamatan Denpasar utara pada tahun pelajaran 2017/2018 Untuk lebih jelasnya dapat dilihat pada tabel berikut

Yang menjadi objek penelitian ini adalah peningkatan prestasi belajar Bahasa Indonesia siswa kelas III Semester I SD Negeri 2 Peguyangan tahun pelajaran 2017/2018 setelah menerapkan latihan terbimbing dengan pendekatan kontruktivisme

Untuk mengumpulkan data dalam penelitian ini dilakukan dengan tes prestasi belajar. Metode yang digunakan untuk menganalisis data hasil penelitian ini adalah metode deskriptif. Untuk data kuantitatif dianalisis dengan mencari mean, median, modus, membuat interval kelas dan melakukan penyajian dalam bentuk tabel dan grafik.

Dalam penelitian ini diusulkan tingkat keberhasilan prestasi belajar siswa pada siklus I mencapai nilai rata-rata 69 dengan ketuntasan belajar minimal $80 \%$ dan pada siklus II mencapai nilai rata-rata 73 atau lebih dengan prosentase ketuntasan belajar minimal $80 \%$.

\section{LATIHAN TERBIMBING DENGAN PENDEKATAN KONTRUKTIVISTIK}

Metode latihan terbimbing yang digunakan dalam proses pembelajaran akan menciptakan kondisi siswa yang aktif. Dalam menggunakan metode tersebut guru harus berhati-hati karena hasil dari suatu latihan terbimbing akan tertanam dan kemudian menjadi kebiasaan. Selain untuk menanamkan kebiasaan metode, latihan terbimbing ini juga dapat menambah kecepatan, ketepatan dan kesempurnaan dalam melakukan sesuatu, serta dapat pula dipakai sebagai suatu cara untuk mengulangi bahan yang telah dikaji (Andri Wicaksono, 2011).

Dalam latihan terbimbing diupayakan agar siswa dapat membangun pengetahuan dan pemahamannya sendiri dengan bantuan dari guru. Pendekatan kontruktivistik juga mendorong siswa untuk memaknai sendiri gejala-gejala alam yang terjadi di lingkungan mereka.

\section{Kelebihan dan Kekurangan Pendekatan Konstruktivisme}

Pada dasarnya tidak terdapat pendekatan, strategi, metode, aya atau pola mengajar yang paling baik untuk semua materi pelajaran, yang ada adalah sesuai atau tidak dengan materi pelajaran pada waktu dan kondisi pelaksanaannya. Oleh karena itu guru diharapkan menguasai berbagai macam pendekatan, strategi, metode, gaya atau pola mengajar sebab setiap pendekatan, strategi, metode, gaya atau pola mengajar memiliki kelebihan dan kekurangan.

Kelebihan dan Kekurangan dalam menggunakan model konstruktivisme menurut Sidik (2008) yang dikutip dari tautan Hamsa adalah:

A. Kelebihan

1. Pembelajaran berdasarkan konstruktivisme memberikan kesempatan kepada siswa untuk mengungkapkan gagasan secara eksplisit dengan menggunakan bahasa siswa sendiri, berbagi gagasan dengan temannya, dan mendorong siswa memberikan penjelasan tentang gagasannya.

2. Pembelajaran berdasarkan konstruktivisme memberi 
pengalaman yang berhubungan dengan gagasan yang telah dimiliki siswa atau rancangan kegiatan disesuaikan dengan gagasan awal siswa agar siswa memperluas pengetahuan mereka tentang fenomena dan memiliki kesempatan untuk merangkai fenomena, sehingga siswa terdorong untuk membedakan dan memadukan gagasan tentang fenomena yang menantang siswa.

b. Kekurangan

1. Siswa mengkonstruksi pengetahuannya sendiri, tidak jarang bahwa hasil konstruksi siswa tidak cocok dengan hasil konstruksi para ilmuan sehingga menyebabkan miskonsepsi.

2. Konstruktivisme menanamkan agar siswa membangun pengetahuannya sendiri, hal ini pasti membutuhkan waktu yang lama dan setiap siswa memerlukan penanganan yang berbeda-beda.

\section{Ciri-Ciri Pembelajaran Secara Konstuktivisme}

Adapun ciri - ciri pembelajaran secara kontruktivisme adalah

1. Memberi peluang kepada murid untuk mendapatkan pengetahuan baru melalui proses terlibat secara langsung

2. Menggunakan ide yang dimiliki setiap siswa untuk bisa mengembangkan dirinya sendiri

3. Pembelajaran dilakukan sesuai dengan minat siswa

4. Ide siswa merupakan proses belajar siswa untuk mencapai tujuan

5. Mengembangkan potensi dan kreatifitas siswa

6. Dalam proses pembelajaran siwa berinteraksi aktif dengan guru
http://ejournal.ihdn.ac.id/index.php/AW

7. Menganggap pembelajaran sebagai suatu proses yang penting sehingga sesuai dengan hasil pembelajaran.

8. Menggalakkan proses inkuiri murid melalui kajian dan eksperimen.

Langkah-langkah Konstruktivisme

1. Pada bagian ini akan dibahas proses belajar dari pandangan kontruktifistik dan dari aspekaspek siswa, peranan guru, sarana belajar, dan evaluasi belajar.

2. Proses belajar kontruktivistik secara konseptual proses belajar jika dipandang dari pendekatan kognitif, bukan sebagai perolehan informasi yang berlangsung satu arah dari luar kedalam diri siswa kepada pengalamannya melalui proses asimilasi dan akomodasi yang bermuara pada pemuktahiran struktur kognitifnya. Kegiatan belajar lebih dipandang dari segi rosesnya dari pada segi perolehan pengetahuan dari pada fakta-fakta yang terlepaslepas.

3. Peranan siswa. Menurut pandangan ini belajar merupakan suatu proses pembentukan pengetahuan. Pembentukan ini harus dilakukan oleh si belajar. Ia harus aktif melakukan kegiatan, aktif berfikir, menyusun konsep, dan memberi makna tentang hal-hal yang sedang dipelajari. Guru memang dapat dan harus mengambil prakarsa untuk menata lingkungan yang memberi peluang optimal bagi terjadinya 
4. belajar. Namun yang akhirnya paling menentukan adalah terwujudnya gejala belajar adalah niat belajar siswa itu sendiri.

5. Peranan guru. Dalam pendekatan ini guru atau pendidik berperan membantu agar proses pengkontruksian pengetahuan oleh siswa berjalan lancar. Guru tidak mentransferkan pengetahuan yang telah dimilikinya, melainkan membantu siswa untuk membentuk pengetahuannya sebdiri.

6. Sarana belajar. Pendekatan ini menekankan bahwa peranan utama dalam kegiatan belajar adalah aktifitas siswa dalam mengkontruksi

pengetahuannya sendiri. Segala sesuatu seperti bahan, media, peralatan, lingkungan, dan fasilitas lainnya disediakan untuk membantu pembentukan tersebut.

7. Evaluasi. Pandangan ini mengemukakan bahwa lingkungan belajar sangat mendukung munculnya berbagai pandangan dan interpretasi terhadap realitas, kontruksi pengetahuan, serta aktifitas-aktifitas lain yang didasarkan pada pengalaman.

\section{PRESTASI BELAJAR BAHASA INDONESIA}

Prestasi belajar adalah
penguasaan pengetahuan atau
ketrampilan yang dikembangkan oleh
mata pelajaran, lazimnya ditunjukan
dengan nilai atau angka yang diberikan
oleh guru..Prestasi belajar adalah suatu
proses usaha yang dilakukan seseorang
untuk memperoleh suatu perubahan
tingkah laku yang baru secara
keseluruhan, sebagai rasil

pengalamannya sendiri dalam interaksi dengan lingkungannya, Slameto (2003: 185). Dari beberapa pengertian di atas pada intinya bahwa prestasi belajar adalah hasil perubahan kemampuan yang dicapai dari suatu kegiatan belajar yang dapat diukur dengan alat atau tes.Adapun kunci pokok untuk memperoleh ukuran dan data hasil belajar siswa adalah dengan mengetahui garis-garis besar indikator (petunjuk adanya prestasi tertentu) dikaitkan dengan jenis prestasi yang hendak diukur. Indikator prestasi belajar siswa dalam penelitian ini dilihat melalui ranah kognitif, yaitu dengan memberikan tes atau soal-soal

\section{Pengertian bahasa Indonesia.}

Bahasa merupakan alat komunikasi melalui Bahasa manusia dapat saling berkomunikasi (Depdikbud, 1993 : 15). Artinya melalui bahasa manusia saling berbagi pengalaman saling belajar dari yang lain serta dapat meningkatkan kemampuan intelektual sehingga lebih komunikatif..

(A) Tujuan Secara umum tujuan pembelajaran bahasa Indonesia adalah sebagai berikut:(1). Siswa menghargai dan membanggakan bahasa Indonesia sebagai bahasa persatuan (nasional) dan bahasa negara. (2). Siswa memahami bahasa Indonesia dari segi bentuk, makna, dan fungsi, serta menggunakannya dengan tepat dan kreatif untuk bermacam-macam tujuan, keperluan, dan keadaan. (3). Siswa memiliki kemampuan menggunakan bahasa Indonesia untuk meningkatkan kemampuan intelektual, kematangan emosional, dan kematangan sosial.

(4). Siswa memiliki disiplin dalam berpikir dan berbahasa (berbicara dan menulis). (5). Siswa mampu menikmati dan memanfaatkan karya sastra untuk mengembangkan kepribadian, memperluas wawasan 
kehidupan, serta meningkatkan pengetahuan dan kemampuan berbahasa. (6). Siswa menghargai dan membanggakan sastra Indonesia sebagai khazanah budaya dan intelektual manusia Indonesia.

\section{HASIL PENELITIAN DAN PEMBAHASAN}

Dasar pelaksanaan penelitian tindakan ini adalah belum tuntasnya prestasi belajar siswa pada pelajaranBahasa Indonesia, di SD Negeri 2 Peguyangan dikarenakan kurang maksimalnya pemanfaatan sarana, media, metode dan strategi pembelajaran yang diterapkan. Kenyataan tersebut, mengarahkan peneliti untuk melaksanakan dan mencapai tujuan penelitian tindakan yang diharapkan, yaitu; (1) untuk memperbaiki praktik pembelajaran yang dilakukan sebaga koreksi diri; (2) untuk pengembangan profesional dalam arti meningkatkan pemahaman guru sebagai peneliti terhadap praktik pembelajaran yang dilaksanakannya; dan (3) untuk memperbaiki keadaan atau situasi yakni prestasi belajar siswa.

\section{Analisis}

\section{a. Observasi/Pengamatan siklus I}

Hasil yang diperoleh seluruh kegiatan peningkatan mutu pembelajaran di SD Negeri 2 Peguyangan dari 37 orang di kelas yang di teliti ada 5 orang siswa memperoleh nilai atas KKM, ada 15 orang memperoleh nilai sama dengan KKM dan ada 15 orang memperoleh nilai KKM adalah 40,54\% yang memperoleh nilai diatas KKM adalah 13,51 \% dan yang belum mencapai KKM adalah $\quad 45,95 \% \quad$ selanjutnya diberikan analisisi kuantitatifnya mengingat data yang diperoleh adalah dalam bentuk angka sebagai berikut: Untuk data yang diperoleh pada siklus I ini dilakukan analisis kuantitatif dengan hasil rinci sebagai berikut:

1. Rata-rata (mean) dihitung dengan:

$$
\frac{\text { Jumlah nilai }}{\text { Jumlah siswa }}=\frac{.2 .520}{37}=68,11
$$

2. Median (titik tengahnya) dicari dengan mengurut data/nilai siswa dari yang terkecil sampai terbesar. Setelah diurut apabila jumlah data ganjil maka mediannya adalah data yang ditengah. Kalau jumlahnya genap maka dua data yang di tengah dijumlahkan dibagi 2 (dua). Untuk median yang diperoleh dari data siklus I dengan menggunakan cara tersebut adalah: 70

3. Modus (angka yang paling banyak/paling sering muncul) setelah diasccending/diurut. Angka tersebut adalah: 70

4. Untuk persiapan penyajian dalam bentuk grafik maka halhal berikut dihitung terlebih dahulu.

a. Banyak kelas $(\mathrm{K})=1+3,3$

$$
x \log (N)=5,95 \rightarrow 6
$$

b.

(r)

Rentang kelas

skormaksimum-skor minimum $=75-60=15$.

$$
\begin{aligned}
& \text { c. } \\
& \text { interval (i) } \\
& 2,50 \rightarrow 3
\end{aligned}
$$

\section{b. Observasi/Pengamatan siklus II}

1. Rata-rata (mean) dihitung dengan: $\frac{\text { Jumlah nilai }}{\text { Jumlah siswa }}=\frac{2685}{37}=72,56$

2. Median (titik tengahnya) dicari dengan mengurut data/nilai siswa dari yang terkecil sampai terbesar. 
Setelah diurut apabila jumlah data ganjil maka mediannya adalah data yang ditengah. Kalau jumlahnya genap maka dua data yang di tengah dijumlahkan dibagi 2 (dua). Untuk median yang diperoleh dari data siklus I dengan menggunakan cara tersebut adalah: 70 .

3. Modus (angka yang paling banyak/paling sering muncul) setelah diasccending/diurut. Angka tersebut adalah: 70

4. Untuk persiapan penyajian dalam bentuk grafik maka hal-hal berikut dihitung terlebih dahulu. Banyak kelas $(\mathrm{K})=1+3,3 \times \log$ $(\mathrm{N})=1+(3,3 \times 1,5)=6,45=6$ Rentangkelas (r) $\quad=$ skormaksimum - skor minimum $=80-65$
$=15$

3. Panjang kelas interval (i)

\section{c. Pembahasan}

Melalui bimbingan dan motivasi dari temannya, Data yang diperoleh peneliti dari hasil tes prestasi belajar di siklus II menunjukkan bahwa kemampuan anak dalam mengikuti pelajaran sudah baik. Ini terbukti dari rata-rata nilai anak mencapai 72,56. Dengan memperhatikan perbandingan nilai awal, nilai siklus I dan nilai siklus II, terjadi kenaikan yang signifikan, yaitu dari rata-rata nilai awal adalah $45,94 \%$ naik di siklus I menjadi $54,05 \%$ dan di siklus II naik menjadi 97,30\% Kenaikan ini menunjukkan upaya maksimal yang dilaksanakan peneliti demi peningkatan mutu pendidikan dan kemajuan pendidikan khususnya di SD Negeri 2 Peguyangan Dalam hal ini, terjadi keselarasan hubungan antara metode latihan terbimbing dengan pendekatan model pembelajaran

konstruktivistik,meningkatnya

intensitas hasil tercapainya dan terwujudnya prestasi belajar yang diharapkan

\section{SIMPULAN}

Berdasarkan hasil penelitian dan pembahasan dapat diambil kesimpulan sebagai berikut bahwa penggunaan latihan terbimbing dengan pendekatan moel pembelajaran kontruktivistik dapat meningkatkan prestasi belajar Bahasa Indonesia siswa kelas III semester I tahun ajaran 2017/2018 di SD Negeri 2 Peguyangan.

Ini terbukti dari perbandingan hasil yang diperoleh dari data awal, yang kemudian dijadikan dasar pertimbangan pelaksanaan tindakan siklus I dan siklus II pada penelitian ini. Hasil tersebut disampaikan sebagai berikut:

a. Dari data awal ada 20 siswa


pada siklus I menurun menjadi 17 siswa dan siklus II hanya 1 siswa mendapat nilai di bawah 70 (KKM).

b. Dari rata-rata awal 60,5 , naik menjadi 68,11pada siklus I, dan pada siklus II naik menjadi 72,56.

c. Dari data awal siswa yang tuntas hanya 17 orang sedangkan pada siklus I menjadi lebih banyak yaitu 20 siswa dan pada siklus II menjadi 36 siswa mencapai ketuntasan belajar yang ditetapkan. Dengan hasil tersebut maka dapat disimpulkan bahwa penerapan latihan terbimbing dengan pendekatan model pembelajaran kontruktivisme sudah dapat meningkatkan prestasi belajar bahasa Indonesia siswa kelas III Semester I SD Negeri 2 Peguyangan tahun pelajaran 2017/2018.

\section{DAFTAR PUSTAKA}

Andri Wicaksono,2011Model Pembelajaran Menulis Cerpen Metode Latihan Terbimbing. 
http://andriew.blogspot.com/2011/0 3/model-pembelajaran-menuliscerpen_2534.html.

Departemen Pendidikan Nasional. 2007. Pedoman Penyusunan Kurikulum Tingkat Satuan Pendidikan Tingkat Pendidikan Dasar dan Menengah. Jakarta. Direktorat Jenderal Manajemen Pendidikan Dasar dan Menengah

Mahmuddin, 2009.Pendekatan Konstruktivistik dalam Pembelajaran. http://mahmuddin.wordpress.com/2 009/11/12/pendekatankonstruktivistik-dalampembelajaran/

Peraturan Menteri Pendidikan Nasional No. 41 Tahun 2007 Tanggal 23 November 2007. Jakarta: Depdiknas.

Depdikbud. 1994. Petunjuk Pelaksanaan Proses Belajar-
http://ejournal.ihdn.ac.id/index.php/AW

Mengajar. Jakarta: Direktorat Pendidikan Menengah Umum.

Depdiknas. 2011. Membimbing Guru dalam Penelitian Tindakan Kelas. Jakarta: Pusat Pengembangan Tenaga Kependidikan, Badan Pengembangan Sumber Daya Manusia Pendidikan dan Penjaminan Mutu Pendidikan.

Djamarah, Syaful Bahri. 2002. Prestasi Belajar dan Kompetensi Guru. Surabaya: Usaha Nasional.

Sardiman, A.M. 1988. Interaksi dan Motivasi Belajar-Mengajar Pedoman bagi Guru dan Calon Guru. Jakarta: Rajawali Pers.

Slamet, PH. 2004. MBS, Life Skill, KBK, CTL dan Saling Keterkaitannya. Makalah yang Disampaikan pada Semiloka DBEP di NTB dan Bali.

Slameto. 2000. Belajar dan FaktorFaktor yang Mempengaruhinya. Jakarta: Rineka Cipta 